\title{
Industrial Estate and Export Decision of Manufacturing Firms in Indonesia
}

\author{
Meindra Sabri ${ }^{\mathrm{a}}$ \\ Statistics Indonesia \\ Nachrowi D. Nachrowi ${ }^{\mathrm{b}}$ \\ Universitas Indonesia \\ Widyono Soetjipto ${ }^{c}$ \\ Universitas Indonesia \\ Maddaremmeng A. Panennungi ${ }^{d}$ \\ Universitas Indonesia
}

\begin{abstract}
Industrial estates may influence a firm's decision to export through better facilities and agglomeration economies. This paper investigates whether a firm's export decision in the industrial estate is better than those outside. We then assess how industrial estate characteristics determine a firm's decision to export.

Treatment effect methods are used to compare a firm's decision to export for those inside and outside of the industrial estate. A probit model is developed to assess how industrial estate characteristics (port distance, port capacity, electricity, water, number of tenants and fiscal incentive) affect a firm's decision to export. We conduct a qualitative analysis through in-depth interviews with industrial estate top level managers and related institutions.

The results show that a firm's decision to export in the industrial estate was better. At the national level, industrial estate characteristics that affect firm's export decision are water sources and fiscal incentives. At the regional level, especially in the Greater Jakarta area, almost all of the characteristics affected a firm's decision to export. Utilities such as electricity and water sources positively affect a firm's decision to export. Agglomeration economies which is represented by number of tenants and government fiscal policy is effective in increasing a firm's decision to export.
\end{abstract}

Keywords: Export, Indonesia, industrial estate, manufacturing firm JEL classification: F12

a Statistics Indonesia, JI. Dr. Sutomo 6-8, Jakarta 10710, Indonesia. The author is also affiliated to the Faculty of Economics and Business, Universitas Indonesia. Email: meindra@bps.go.id

b Faculty of Economics and Business, Universitas Indonesia, Kampus Baru UI Depok, Jawa Barat - 16424, Indonesia. Email: nachrowi@ui.ac.id, gnachrowi@gmail.com (Corresponding author)

c Faculty of Economics and Business, Universitas Indonesia, Kampus Baru UI Depok, Jawa Barat - 16424, Indonesia. Email: widyono@lpem-ui.org

d Faculty of Economics and Business, Universitas Indonesia, Kampus Baru UI Depok, Jawa Barat - 16424, Indonesia. Email: maddaremmeng.panennungi@ui.ac.id

Article Info: Received 20 September 2017; Revised 16 April 2018; Accepted 19 July 2018

https://doi.org/10.22452/MJES.vol55no2.3 


\section{Introduction}

Economic zones are promoted by many governments around the world to spur economic growth and competitiveness. The economic zone may be located in a particular and fenced area such as industrial park (IP), export processing zone (EPZ), eco-industrial park (EIP), technology park (TP) or innovation district (ID). Economic zones can also cover a wide geographical area such as the special economic zone (SEZ) in Penang, Malaysia and Shenzhen, China. Another type is an area with a port that is concentrated for trade and logistics activities like Singapore and Dubai.

The Government of Indonesia (GOI) has been trying to boost exports of the manufacturing industry through the development of industrial estates by locating manufacturing firms in a proper, correct and environmentally friendly area, so that the industry can become more efficient and makes it easier for future development (Ministerial Industry Decree No. 35, 2010). Industrial estates are generally open to export-oriented firms or non export-oriented ones. Some of them have an EPZ or a bonded zone in their area.

Industrial estates were initially managed by the government through state-owned enterprises (SOEs) which developed the Jakarta Industrial Estate Pulo Gadung (JIEP) in 1973, Surabaya Industrial Estate Rungkut (SIER) and Cilacap Industrial Zone (1974). These were followed by the Medan Industrial Estate (1975), Makassar Industrial Estate (1978), Cirebon Industrial Estate (1984), and Lampung Industrial Estate (1986). The role of the private sector in the development of industrial estates started after the release of Government Regulation No. 53, 1989 whereby the industrial estate can be managed by the private sector (domestic and foreign) with or without government participation.

The development of industrial estates has a positive impact on Indonesia's manufacturing export. The Ministry of Industry of the Republic of Indonesia estimated that the value of exports from industrial estates was US\$52 billion per year or 41 percent of the total value of non-oil exports in 2012. Industrial estates can still be optimised because land usability is only 58 percent and there is high demand for land which is up to 1000 ha/year especially in Jakarta and the surrounding areas ${ }^{1}$ (Kementerian Perindustrian, 2012). Furthermore, since 2009 through Government Regulations No. 24/2009 concerning Industrial Estates, industries are required to be located in industrial estates. The growing number of firms located in the industrial area is expected to increase the number of exporters. The effort to increase manufacturing exports is not only through boosting the values of existing exports but also by increasing the number of exporters (Koenig, 2009).

Two questions arise from the focus on increasing the number of exporters. First, how effective are industrial estates in encouraging a firm's export decision. We would like to evaluate whether the industrial estate is effective in encouraging exports by comparing the export decision of firms located inside and outside of the industrial estate. The main problem that arises when comparing a firm's export decision is the firm's self-selection to be located in the industrial estate. Locating in an industrial estate

1 Bogor, Tangerang, Bekasi, Karawang, Purwakarta and Bandung. 
might be more beneficial for firms and make them have a higher propensity to export than being located outside of the industrial estate. This self-selection into industrial estate might result in an upwardly biased estimate of the causal effects on firm's export decision. To solve this problem, we use statistical analysis of cause and effect based on the framework of potential outcomes using the Rubin Causal Model (RCM). We need to estimate the potential outcome of treated firms (in the industrial estate) if they had located elsewhere. This counterfactual is inherently unobservable, but we can find the average treatment on the treated (ATT) value base on similar observable covariates under the unconfoundedness and overlap assumptions. Studies related to the comparison of export performance inside and outside economic zones indicate that special economic areas have a positive influence on the export of firms. Schminke and Bieselbroeck (2013) showed that firms in specialised areas such as economic and technological development zones (ETDZs) and science and technology industrial parks (STIPs) in China have a higher total value of exports than firms outside of the two regions. Yi and Wang (2012) stated that firms in an economic zone are more likely to export compared to firms outside the economic zone.

The second question is, what are the industrial estate characteristics that determined firm's decision to export? Previous studies showed that a firm's decision to export is determined by both internal and external factors. The internal factors, firm-specific determinants are associated with internal economies of scale such as age, size and productivity (Aitken, Hanson, \& Harrison, 1997; Bernard \& Jensen, 1999; Greenaway \& Kneller, 2004; Roberts \& Tybout, 1997; Zhao \& Zou, 2002). The external factors involved external economies of scale regarding agglomeration (Bernard \& Jensen, 2004; Greenaway \& Kneller 2008; Koenig, 2009). Agglomeration is the benefit that firms would acquire by locating close to each other in a city or industrial estate as compared to being separately located (Glaeser, 2010). In these studies, a firm's location was merely indicated by a regional dummy variable. The characteristics of the regions were not fully explored as determinants of a firm's decision to export.

In a recent approach, Farole and Winkler (2011) and Rodriguez-Pose, Tselios, Winkler and Farole (2013) found that regional characteristics influenced a firm's decision to export, but the regional characteristics were unable to capture the differences among industrial estates that are located within the same regional area. In a region, there can be more than one industrial estate where each has different transportation costs, infrastructure and number of tenants that can affect the costs of exporting. The industrial estate characteristics that influence a firm's decision to export need to be explored because they are related to cost savings from exporting in each industrial estate as depicted in Figure 1.

Concentration of firms in the regional level has a significant effect on firm's export decision. Winkler (2013) found that firms in the core region are twice as likely to be exporters as those outside the core in Indonesia ${ }^{2}$. Based on the concentration of industrial estates, we set the Greater Jakarta area which covers Bekasi, Karawang, Bogor, Purwakarta, Tangerang, Serang and Bandung as the core with over 50 percent of

2 Core region is defined as a region with most firms (Jakarta and West Java). 


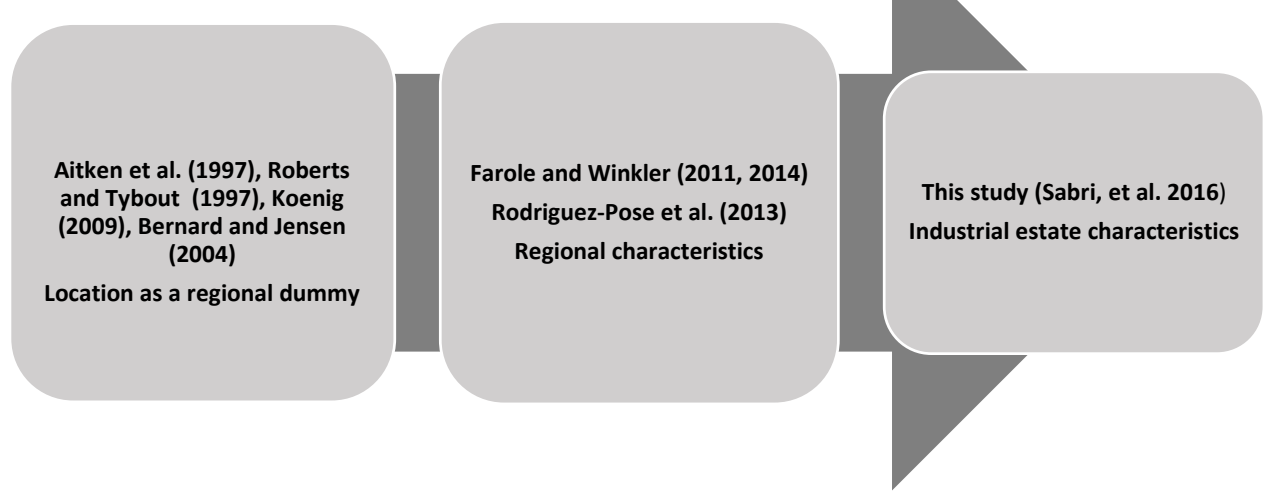

Figure 1. Research position related to a firm's decision to export

total industrial estates. Another region such as North Sumatera, West Sumatera, Riau, Riau Islands, Lampung, Central Java, East Java, South Sulawesi, and East Kalimantan is defined as outside the Greater Jakarta area.

This study is restricted to two aspects. First, the research was done on the industrial estate which has an area of at least 50 hectare, following the survey of the Ministry of Industry. ${ }^{3}$ Second, the study is limited to the effect of characteristics of the industrial estate on a firm's decision to export. Many exporting firms in an industrial estate export via a third party. This kind of firm does not report the export transaction thus making it difficult to keep track the value of export.

We contribute to the empirical study of a firm's decision to export in Indonesia. First, we evaluate the effectiveness of industrial estate on export decisions by comparing firms located inside and outside of the industrial estate. Then we assessed characteristics of the industrial estate that can reduce the costs of exporting such as transportation costs, availability of infrastructure, local agglomeration and government policy in fiscal incentive. To the best knowledge of the authors, a study on the role of characteristics of the industrial estate in affecting firm's export decision has never been conducted (see Figure 1). We try to fill this gap by providing a complete analysis on the effect of the industrial estate characteristics in the same region.

This paper is organised as follows. After the Introduction in Section 1, Section 2 explains the type of economic zone and discusses the industrial estate characteristics that may affect a firm's decision to export. In Section 3, we outline the methodology and data. The results on the treatment effect to compare export decision of firms inside and outside of the industrial estate by controlling firms' self-selection into industrial estate, and a probit regression to assess the role of industrial estate characteristics on a firm's export decision are discussed in Section 4. We close with conclusions in Section 5.

3 According to the Ministry of Industry regulation, industrial estates should have a minimum area of 50 hectare. 


\section{Literature Review}

\subsection{Economic Zone}

A strategic location may influence a firm's decision to export. Being located in the same location with other firms can benefit a firm through economies of scale and agglomeration economies. Marshall (1890) introduced localisation economies where firms receive benefit from others in the same industry through the availability of intermediate input providers with a lower price, access to a large pool of specific skills labour and development of new ideas or technology. Jacobs (1970) also argued that firms may benefit from externalities arising in regions with diverse industrial structures, or from urbanisation economies. Firms can observe and adapt ideas from others.

Localisation of industries in a particular area is generally due to market forces. However, many governments in the world built some planned areas known as economic zones to spur economic growth and competitiveness. Economic zones, based on objectives, activities and markets can be divided into six types as described in Table 1.

Firms in the economic zone may have advantages through economies of scale and agglomeration (World Bank, 2009). Previous studies showed mixed results. Warr (1989) found that the establishment of export processing zone (EPZ) in Indonesia, the Republic of Korea, Malaysia, and the Philippines failed to fulfill hopes of economic gains through employment, foreign exchange earnings and technology transfer. On the other hand, Wahyuni, Anoviar and Santoso (2012) found that the successful Penang special economic zone has recorded the highest investment in Malaysia since 2010.

Table 1. Types of economic zone

\begin{tabular}{|c|c|c|c|c|}
\hline Type of zone & Objective & Activities & Market & Example in Indonesia \\
\hline $\begin{array}{l}\text { Free trade zone } \\
\text { (commercial } \\
\text { free zone) }\end{array}$ & Support trade & $\begin{array}{l}\text { Entrepôt and } \\
\text { trade-related } \\
\text { activities }\end{array}$ & $\begin{array}{l}\text { Domestic, } \\
\text { re-export }\end{array}$ & $\begin{array}{l}\text { Batam, Bintan, } \\
\text { Karimun }\end{array}$ \\
\hline Traditional EPZ & $\begin{array}{l}\text { Export } \\
\text { manufacturing }\end{array}$ & $\begin{array}{l}\text { Manufacturing, } \\
\text { other processing }\end{array}$ & Mostly export & Bonded zone \\
\hline Hybrid EPZ & $\begin{array}{l}\text { Export } \\
\text { manufacturing }\end{array}$ & $\begin{array}{l}\text { Manufacturing, } \\
\text { other processing }\end{array}$ & $\begin{array}{l}\text { Export and } \\
\text { domestic }\end{array}$ & \\
\hline Freeport & $\begin{array}{l}\text { Integrated } \\
\text { development }\end{array}$ & Multi-use & $\begin{array}{l}\text { Domestic, internal, } \\
\text { and export }\end{array}$ & $\begin{array}{l}\text { Special economic } \\
\text { zone }\end{array}$ \\
\hline $\begin{array}{l}\text { Enterprise zone, } \\
\text { Empowerment, } \\
\text { Urban free zone }\end{array}$ & $\begin{array}{l}\text { Urban } \\
\text { revitalisation }\end{array}$ & Multi-use & Domestic & $\begin{array}{l}\text { Integrated economic } \\
\text { development zone } \\
\text { (KAPET) }\end{array}$ \\
\hline $\begin{array}{l}\text { Single factory } \\
\text { EPZ }\end{array}$ & $\begin{array}{l}\text { Export } \\
\text { manufacturing }\end{array}$ & $\begin{array}{l}\text { Manufacturing, } \\
\text { other processing }\end{array}$ & Export & $\begin{array}{l}\text { Bonded zone that is } \\
\text { located outside the } \\
\text { industrial estate }\end{array}$ \\
\hline
\end{tabular}

Source: Akinci and Crittle (2008). 
Research on the comparison of export performance between firms inside and outside of the economic zone has never been conducted on Indonesia. As for studies on other countries, Yi and Wang (2012) found that firms in an economic zone are more likely to export compared to firms outside the economic zone. Schminke and Bieselbroeck (2013) showed that export performances of firms in economic and technological development zones (ETDZs), and the science and technology industrial parks (STIPs) were better than firms outside of both areas in China.

One of the economic zones in Indonesia is the industrial estate. Industrial estate is defined as a centre of industrial activity equipped with facilities and infrastructure which is developed and maintained by the industrial estate management. Industrial estate is open to export-oriented firms or domestic market only. As shown in Table 1, based on the type, industrial estates are unclassified, because it can be a hybrid EPZ and located in free trade zone or special economic zone. According to a survey of the Ministry of Industry, by 2012 there were at least 59 industrial estates with a minimum area of 50 ha. They are spread across Indonesia but more concentrated in the Greater Jakarta area (53 percent).

To evaluate the effectiveness of the industrial estate on a firm's decision to export, we compare decisions to export of firms inside and outside of the industrial estate. However, we should be aware of a firm's self-selection problem which might result in an upwardly biased estimation. Statistical analysis of cause and effect based on potential outcome framework is used to overcome this problem. We estimate the potential outcome of treatment firms (in the industrial estate) if they are located elsewhere using the treatment effect methods.

\subsection{Determinant of Firm's Export Decision in the Industrial Estate}

In line with the theory, firms will choose to export if the expected profit when exporting is higher than expected profit when operating only in the domestic market. Their location in the industrial estate might influence the expectations of firm profits through cost savings from trade costs and economies of scale. Trade costs are costs in addition to production costs, incurred until the goods are received by consumers (transportation, tariff and non-tariff, information cost, etc.), and the economies of scale are obtained savings through the firm's size, output or scale of operations that cause the cost per unit of output to decline.

Transportation costs are part of the trading costs that can affect a firm's decision to export (Krugman, Obstfeld, \& Melitz, 2012). We use the distance from the firm location to the seaport and seaport capacity to proxy the transportation costs. A farther distance increases the costs of transportation, so we expect that the distance to the seaport of export negatively affects a firm's decision to export. Yi and Wang (2012) found that firms that were located near coastal areas were more likely to export than those located on the mainland. The seaport capacity is expected to positively affect a firm's decision to export through a reduction in transportation costs. Abe and Wilson (2011) found that a 10 percent increase in port capacity reduced transport costs by up to 3 percent in East Asia. 
Porter (1998) stated that the development of a region or industrial cluster needs government involvement, particularly for providing adequate infrastructure. The stateowned electricity company (SEC) and the state-owned water supply company (WSC) are part of the infrastructure provided by the government. According to the state regulations, the availability of sources of electricity to the industrial area is guaranteed to be uninterrupted. The price is relatively lower than that of privately owned power supply, which can reduce the cost of production. The WSC plays a crucial role in the industrial estates that do not have natural water sources such as rivers. The industrial estates that are not served by SWC distribution have to build their water treatment plants which can significantly increase production costs.

Various types of industries in an industrial estate can form economic urbanisation as part of agglomeration. As the number of firms operating in the industrial estate increases, competition will also increase, which leads to the firm being more productive and increases the tendency to export (Long and Zang, 2011). Agglomeration can influence a firm's decision to export through reducing costs of exporting (Aitken et al., 1997) and raising productivity. Agglomeration can lower production costs through sharing of infrastructure and information and lower transportation and transactions costs through better relation of suppliers and customers (Malmberg, 2009). However, Krugman (1991) stated that in addition to the forces that drive agglomeration (centripetal forces), there is also the forces that are against agglomeration (centrifugal forces) and characterised by congestion costs. Congestion costs can raise production costs through higher price of inputs (land, capital and labour) and transportation and transactions costs, through longer waiting times (e.g., mobility of intermediate inputs or licences). These costs may counterbalance gains from agglomerations, and the net effect can be either positive or negative.

Firms that are located in an EPZ or bonded zone which is part of an industrial estate receive fiscal incentive through various taxes. Exemptions of import tariff and tax for intermediate input and machinery are given to firms that produce for the export market. This fiscal incentive allows the exploitation of scale economies in production. More firms having fiscal incentives are expected to influence the decisions of other firms in the industrial estate to export. This effect is known as export spillover. Previous studies have shown positive effects such as Farole and Winkler (2011), Koenig (2009), Rodriguez et al. (2013), but Bernard and Jensen (2004) did not find a significant export spillover effect.

Other determinants of export are, but not limited to, export status in the previous year, productivity, number of labour, source of capital, firm's age, and information availability. Export status in the previous year as a proxy for sunk entry costs has a positive influence on a firm's decision to export as found by Farole and Winkler (2011), Narjoko and Atje (2007), Roberts and Tybout (1997) and Rodriguez et al. (2013). Melitz (2003) showed that only firms with a high productivity could export. Labour is an important factor of production because more labour implies more output. Sources of capital, especially from abroad brings technological transfer. The higher the share of foreign capital, the higher the export opportunities. Sjöholm and Takii (2008) found that in Indonesia, firms that used foreign capital are more likely to export than domestically funded firms. However, the influence of age on a firm's export decision 
is still ambiguous. Naudé, Gries and Bilkic (2013) stated that starting time to export was an important strategy. Firms often delayed exporting until the information was available and the requirements such as learning ability, innovation, productivity growth, access to finance were met. Johanson and Vahlne (1977) argued that making the decision to export was a long process, but adequate transportation facility shortened that process.

\section{Methodology}

\subsection{The Treatment Effect}

The treatment effect is used to analyse the effect of the industrial estate on a firm's decision to export. We cannot directly compare a firm's decision to export among those located inside and outside of an industrial estate because it may be affected by the facilities and regulations that support exports. The results will be biased. Treatment effect works with a counterfactual, where each firm has an outcome with and without treatment. In this paper, the outcome is a firm's decision to export, and the treatment is an industrial estate. The average treatment effect on the treated (ATT) is used to measure the difference in mean (average) of both outcomes.

Following Schminke and Bieselbroeck (2013), let $y$ be the outcome variable of performance and $w$ be the binary variable of treatment. There are two potential outcomes even though only one can be observed for each firm. If firm $i$ is in the industrial estate and its potential outcome is $y_{i 1}$, the potential outcome for the same firm when it is located outside of industrial estates is $y_{i 0}$. The average treatment effect (ATE) measures the effect of treatment on a random sample of a particular population, that is, the effects of an average over the entire population. However, not all firms are willing to enter into an industrial estate so the measurement of treatment effect need to be focussed on firms that are located in the industrial estates. This measurement is called the average treatment effect on the treated (ATT). ATT is defined as:

$$
\tau_{a t t} \equiv E\left(\left(y_{1}-y_{0}\right) \mid w=1\right)
$$

Two identifying assumptions are needed to deal with the missing information on $y_{0}$ for the treated firms:

1. Unconfoundedness or ignorability of treatment

$$
\left(y_{1}, y_{0}\right) \perp w \mid \mathbf{x}
$$

This first assumption of unconfoundedness or ignorability of treatment is conditioned on a set of covariates because it makes the firm's presence in the industrial estate becomes random. Covariate variables in $\mathbf{x}$ must be effective in separating the correlation between the potential performance of a firm when it is not located in the industrial estate and the actual value of the firm's performance in the industrial estate.

A weaker assumption of (2) known as an independent mean is used, i.e.

$$
\mathrm{E}\left[\mathrm{y}_{0} \mid \mathbf{x}, \mathrm{w}\right]=\mathrm{E}\left[\mathrm{y}_{0} \mid \mathbf{x}\right]
$$




\section{Overlap}

When conditioned on a set of control variables $\mathbf{x}$, each firm in the population has a potential to get the treatment,

$$
\forall \mathbf{x} \in \chi, 0<P(w=1 \mid \mathbf{x})<1
$$

where $\chi$ is a collection of the covariates. These assumptions guarantee that for each firm in the sample, there is a firm outside of the industrial estate to be used as a control with the same covariates.

In estimating the average treatment effects, we defined ATT as:

$$
\hat{\tau}_{a t t}=\frac{1}{\sum_{i} w_{i}} \sum_{i=1}^{N} w_{i}\left[\widehat{m}_{1}\left(\mathbf{x}_{\mathrm{i}}\right)-\widehat{m}_{0}\left(\mathbf{x}_{\mathrm{i}}\right)\right]
$$

where the function $\widehat{m}_{1}($.$) and \widehat{m}_{0}($.$) are the predicted values of the variable perfor-$ mance of firms in an industrial estate and those outside the industrial estate using the same covariates but can have different coefficients.

This study uses the firm's internal characteristics such as previous year export status productivity, number of employees, percentage of foreign capital, firm's age, sector and location as covariates. Location of the firm is represented by a dummy variable that distinguishes whether the firm is located in the same province. A firm's decision to export is defined as a dummy variable which has a value of 1 if the firm exports and 0 otherwise.

Many estimators can be used to estimate ATT through regression and matching. We use two estimators from regression to estimate ATT. The first estimator is regression adjustment (RA) estimator which uses the difference of the average predicted outcomes for estimating treatment effects. The first step is fitting a regression model of the outcome for firms inside and outside of industrial estate on a set of covariates, and then after the average predicted outcomes are computed, we restrict the computation on firms inside the industrial estate to obtain ATT.

We implement a second estimator as a robustness check. Inverse-probabilityweighted regression adjustment (IPWRA) estimator uses two models to predict treatment status and outcomes. First, we estimate the probability of industrial estate (treatment) on a set of covariates $\mathbf{x}$, compute the propensity score $\hat{p}(\mathbf{x})$, and then compute the inverse-probability weights as follows:

$$
\lambda^{a t t}=w_{i}+\left(1-w_{i}\right) \frac{\hat{p}\left(\mathbf{x}_{i}\right)}{1-\hat{p}\left(\mathbf{x}_{i}\right)}
$$

The inverse-probability weights are used to fit weighted regression models of the outcome for firms inside and outside of the industrial estate, and then the predicted outcomes are calculated. We obtain ATT from the difference of the average of these predicted outcomes. 


\subsection{Probit Regression for Firm's Decision to Export}

The model of a firm's decision to export is referred to Farole and Winkler (2011). The decision to export for firm $i$ at time $t$ depends on the expected revenue $R$ and production costs $c$ and sunk entry costs $S$ when it began to export.

$$
\mathrm{P}\left(\operatorname{Exp}_{\mathrm{it}}=1\right)=\mathrm{P}\left(\mathrm{R}_{\mathrm{it}}>\mathrm{c}_{\mathrm{it}}+\mathrm{S}\left(1-\operatorname{Exp}_{\mathrm{it}-1}\right)\right)
$$

where Exp is export status, and the firm would export if expected profit $\pi_{i t}>0$. $S$ is sunk entry costs, taking a value of 0 if firms export in period $t-1$ and $S$ otherwise. Sunk entry costs can be either gathering information about the conditions of demand or building the distribution system when entering the export market.

Expected profit $\pi^{*}$ it is assumed to be influenced by the characteristics of the industrial estate $I$, firm's internal characteristics $F$, and sunk entry cost $S$ that can increase or decrease the revenue $R$ and cost $c$. Equation (7) is expanded into:

$$
\mathrm{P}\left(\operatorname{Exp}_{\mathrm{it}}=1\right)=\mathrm{P}\left(\pi^{*}{ }_{\mathrm{it}}=\beta \mathrm{I}_{\mathrm{kt}}+\gamma \mathrm{F}_{\mathrm{it}}+\mathrm{S}\left(1-\operatorname{Exp}_{\mathrm{it}-1}\right)>0\right)
$$

Expected profit $\pi^{*}$ it is approximated as a linear combination of $I_{k t}$ (factor of the characteristic industrial estate), $F_{i t}$ (factor of internal characteristics), and sunk entry costs. Subscript $t$ indicates time period, $k$ for the industrial estate, and $i$ for individual firm. Then, using the previous year's export status as a proxy for sunk entry cost, a probit model of a firm's decision to export can be written as:

$$
\begin{aligned}
& \operatorname{Exp}_{i r k, t}=\alpha_{0}+\beta_{1} \text { Inportdistance }_{k t}+\beta_{2} \text { Inportcap }_{k t}+\beta_{3} \text { electricity_pln }_{k t}+ \\
& \beta_{4} \text { water_pam }_{k t}+\beta_{5} \text { tenant }_{k t}+\beta_{6} \text { fiscalincentiveb }_{k t}+\gamma_{1} \text { Exp }_{i k, t-1}+
\end{aligned}
$$

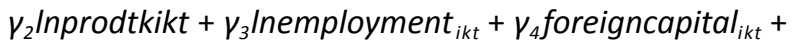

$$
\begin{aligned}
& \nu_{5} a g e_{i k t}+\gamma_{6} a g e 2_{i k t}+\varepsilon_{i k t}
\end{aligned}
$$

where:

Export: Inportdistance: The distance to the seaport in logarithm

Inportcap: Seaport capacity, approached by export volume (thousand tons) in logarithm

electricity_pln: The percentage of the Perusahaan Listrik Negara (PLN) (state-owned power company) electricity usage by total kWh in an industrial estate

water_pam: Dummy variable for water source, 1 if PAM (state-owned water company) and 0 otherwise

tenant: Number of tenants in logarithm

fiscal incentives: The number of the firms that have fiscal incentive divided by the total firms in the industrial estate

Inprodtk: $\quad$ Productivity, calculated from the output value divided by the amount of labour in logarithm

Inemployment: The number of workers in logarithm

foreign capital: Percentage of foreign capital

age:

age $^{2}$ :

Firm's age (years)

Squares of firm's age 


\subsection{In-Depth Interview}

Interviews were conducted to obtain additional information related to the characteristics of the industrial estate that are used in this study. The primary objective of the in-depth interview is to reinforce the results of the quantitative analysis that has been done. The subjects of the interviews are senior executives from some of the industrial estates holding positions as Marketing Manager, General Manager or Chief Executive Officer (CEO). Top executives are considered to have extensive knowledge of the behaviour of tenant and market. Also, interviews are conducted with the Executive Director and Chairman of the Association of Industrial Estate (HKI) for getting information about the condition of industrial estates in Indonesia. HKI plays an important role as a liaison between the government and the industrial estate management. Relating to fiscal incentives, we interviewed the officer of Customs Office in Bekasi.

\subsection{Data}

The database in this study was mainly built from three datasets: (i) industrial estates directory and tenants from the Ministry of Industry, (ii) Large and Medium Industries Survey or Industri Besar dan Sedang (IBS) of Statistics Indonesia or Badan Pusat Statistik (BPS) and (iii) export statistics directory 2011 and 2012 from the BPS. Information on industrial estates characteristic variables such as distance to the seaport, source of water and number of tenants were obtained from the industrial estate directory data. The port capacity was taken from transportation statistics. The percentage of PLN electricity usage by total $\mathrm{kWh}$ in an industrial estate was sourced from IBS, and the number of firms that have bonded area facilities in the industrial estate was sourced from Customs. Meanwhile, all of the firm's internal characteristics were sourced from IBS.

There are some data adjustments for data processing. We aggregate the capacity of the seaport in Batam as a single value since Batam is a small island located in the province of Riau Islands which has several ports for exporting. In contrast, the other provinces in this study have only one main port. The capacity of seaport that we used was export volume (thousand tons) from the seaport. We cannot find the exact capacity of seaport because of differences in measurement. The export status of the firm was matched by export statistics when a missing value was found.

The survey of industrial estate directory conducted by the Ministry of Industry in 2012 covers 59 industrial estates. After checking the existence of large and medium industries, only 48 industrial estates have data of large and medium industrial firms. The reduction occurred because of: (i) the unavailability of tenant data in an industrial estate because the database is still under construction, and (ii) no matching firms with IBS data.

\section{Results}

\subsection{Descriptive Statistics}

When comparing decisions to export for firms located inside and outside of the industrial estate, there are 21,559 firms that consist of 1,583 firms inside the industrial estate and 19,976 firms located elsewhere. For independent variables, we use 
Table 2. Descriptive statistics of variables of firms located inside and outside the industrial estate

\begin{tabular}{|c|c|c|c|c|c|c|c|c|}
\hline \multirow[t]{2}{*}{ Variables } & \multicolumn{4}{|c|}{$\begin{array}{l}\text { Inside industrial estate } \\
1583 \text { firms }\end{array}$} & \multicolumn{4}{|c|}{$\begin{array}{l}\text { Outside industrial estate } \\
19976 \text { firms }\end{array}$} \\
\hline & Mean & Std. dev. & Min & Max & Mean & Std. dev. & Min & Max \\
\hline Export (dummy)* & 0.506001 & & & & 0.171506 & & & \\
\hline $\begin{array}{l}\text { Export last year } \\
\text { (dummy) }^{*}\end{array}$ & 0.49463 & & & & 0.192231 & & & \\
\hline Productivity & 1155028 & 3632149 & 116.068 & $7.40 \times 10^{7}$ & 401750.4 & 1683131 & 58.70834 & $7.65 \times 10^{7}$ \\
\hline Employment & 358.259 & 929.2562 & 20 & 26000 & 202.6572 & 782.9504 & 20 & 41000 \\
\hline $\begin{array}{l}\text { Foreign capital } \\
\text { (\%) }\end{array}$ & 41.64801 & 47.08029 & 0 & 100 & 5.605163 & 21.93982 & 0 & 100 \\
\hline Age & 15.82502 & 9.172546 & 1 & 100 & 19.96551 & 12.87614 & 1 & 111 \\
\hline
\end{tabular}

Note: ${ }^{*}$ Only mean is reported for the dummy variables to indicate the proportion of export as defined in the table.

variables such as the previous year's export status productivity, number of employees, percentage of foreign capital, and firm's age, sector and location. The descriptive statistics of the variables can be seen in Table 2.

Table 2 shows that more than 50 percent of firms in the industrial estate export their products, but the corresponding percentage is only 17.2 percent for firms outside of the industrial estate. The average productivity of firms inside the industrial estate is 1155028 , almost three times of firms' average productivity outside the industrial estate which is 401750 . The number employed inside the industrial estate on the average is 358 , higher than those outside which has an average of 202 employees. Foreign capital shows that an industrial estate is more successful for bringing in investments. The average of foreign investment inside an industrial estate is 41.6 percent, higher than outside the industrial estate which has only 5.6 percent. The average age indicates that firms in the industrial estate are newer than those outside the industrial estate. The average age inside an industrial estate is 15.8 which is smaller than outside the industrial estate with an average age of 19.9.

The descriptive statistics of industrial estate characteristics are divided into the national and regional level. Based on the concentration of industrial estates, we categorised national level into two regions: the Greater Jakarta area which has 24 industrial estate firms located in Jakarta, West Java and Banten, and the outside Greater Jakarta area which has 24 industrial estates and 466 firms located in 9 provinces (North Sumatera, West Sumatera, Riau, Riau Islands, Lampung, Central Java, East Java, South Sulawesi, and East Kalimantan). Table 3 provides an overview of the variables at national and regional level.

The discussion of descriptive statistics focussed on the difference between the variables at the regional level. The percentage of exporting firms in the Greater Jakarta and outside the Greater Jakarta are about 51 percent and 49 percent respectively. These indicate that the firms in the industrial estates in Greater Jakarta are more likely to export than those outside the Greater Jakarta area. 
Industrial Estate and Export Decision of Manufacturing Firms in Indonesia

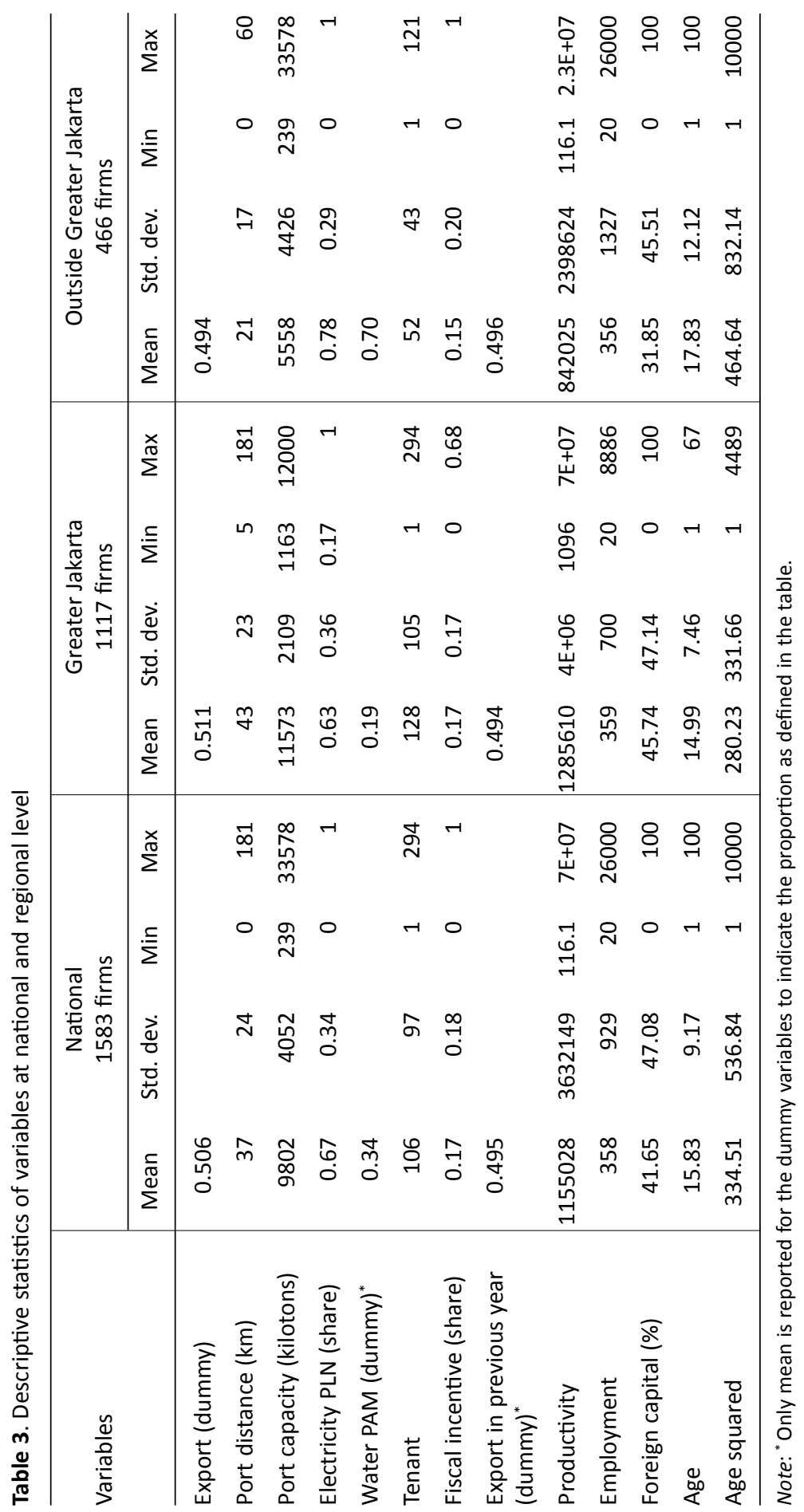


The port distance to the industrial estate in the Greater Jakarta area on average is farther away from the seaport than outside the Greater Jakarta area. It is caused by many industrial estates located in Bekasi, Karawang and Purwakarta. The distance of these locations to the port of Tanjung Priok are further than industrial estates located outside the Greater Jakarta area. The average seaport capacity is higher in the Greater Jakarta area than outside the area. The Greater Jakarta region has fewer ports but has a relatively larger capacity than outside the Greater Jakarta area.

For infrastructure, the average use of PLN power in industrial estates in the Greater Jakarta area is 63 percent, lower than those outside of the Greater Jakarta area that reached 78 percent. This shows the dependence of the industrial estates for PLN power outside the Greater Jakarta area is higher. The PAM water is only used by 19 percent of firms in the industrial estates in the Greater Jakarta area, much lower than outside the Greater Jakarta area which is used by 75 percent of firms. The average number of tenants in the Greater Jakarta area is higher than outside the Greater Jakarta area. Fiscal incentives are on average similar in both regions.

The export status in the previous year shows that the percentage of exporting firms increases about 2 percent at the national level. Most of them are located in the Greater Jakarta area whereas the number of exporting firms outside the Greater Jakarta area is relatively constant. The average productivity in the Greater Jakarta area is closed to the middle value, which shows that firms in the Greater Jakarta area have the same relative productivity as those outside the Greater Jakarta area. The number for labour is relatively similar between the two regions. The average of foreign capital in the Greater Jakarta area is higher than those outside the Greater Jakarta area, showing more firms with foreign capital are located in the Greater Jakarta area. Firms' age in the Greater Jakarta tend to be lower than those outside the Greater Jakarta area.

\subsection{Comparison of Firm's Export Decision Inside and Outside the Industrial Estate}

Comparison of firms' decision to export for those inside and outside the industrial estate is measured using regression adjustment (RA) and inverse-probability-weighted regression adjustment (IPWRA). We report the value of average treatment effects on the treated (ATT) in Table 4.

Both RA and IPWRA have a significant positive value of 0.1327 and 0.1256 respectively. It means that firms in the industrial estate have 13 percent higher probability to export, after controlling for productivity, number of employees, percentage of foreign capital, firm's age, sector and location as the covariates. This result shows that the development of industrial estates is successful in promoting exports.

Table 4. Comparison of decision to export for firms inside and outside the industrial estate

\begin{tabular}{lcc}
\hline ATT & Regression Adjustment & $\begin{array}{c}\text { Inverse-probability-weighted } \\
\text { regression adjustment }\end{array}$ \\
\hline Export Decision & $0.1327^{* * *}$ & $0.1256^{* * *}$ \\
\hline
\end{tabular}




\subsection{Role of Industrial Estate Characteristics on Firm's Export Decision}

At the national level, there are 1583 firms. The Greater Jakarta area has 1117 firms or 71 percent of total observations while outside the Greater Jakarta region has 466 firms or 29 percent of total observations. By using probit models, the estimation of various sets of data is robust to heteroscedasticity. The standard error is clustered by the seaport so that errors can be correlated between firms that access the same seaport. The Hosmer-Lemeshow test shows that the models used are good. Table 5 shows the regression results.

The distance to the seaport has a significant positive effect in the Greater Jakarta area. This means that a greater distance of an industrial estate from the seaport will increase a firm's decision to export, but it is insignificant for outside the Greater Jakarta area. These results contradict the hypothesis that a further distance will increase transportation costs and lower a firm's tendency to export. The possible reason is the economic benefit from production costs outweighed the effect of increasing transportation costs. From the interviews, all industrial estates have highway access to the seaports. The toll road is relatively smooth so that a longer distance does not necessarily increase transportation costs in the Greater Jakarta area.

Seaport capacity has no significant effect on a firm's export decision in the industrial estate in the Greater Jakarta area. There are only two seaports in Greater Jakarta, and most of the firms access the same port (Tanjung Priok). For those outside Greater Jakarta, seaport capacity has a significant negative effect on a firm's export decision. This is caused by non-optimal exporting by manufacturing firms in the outside Greater Jakarta area. A port with larger capacity is accessed by fewer exporting firms. A large share of the port capacity is used by other economic sectors based on natural

Table 5. Results of regression at national and regional Level

\begin{tabular}{lllc}
\hline Variable & National & $\begin{array}{c}\text { Greater Jakarta } \\
\text { area }\end{array}$ & $\begin{array}{c}\text { Outside Greater } \\
\text { Jakarta area }\end{array}$ \\
\hline Port distance & 0.104 & $0.174^{* * *}$ & 0.144 \\
Port capacity & 0.0301 & 0.0493 & $-0.198^{* *}$ \\
PLN Electricity & -0.113 & $0.0348^{* * *}$ & $-0.879^{* * *}$ \\
PAM Water & $0.183^{*}$ & $0.265^{* * *}$ & $-0.365^{* * *}$ \\
Tenants & -0.0224 & $0.0508^{* * *}$ & 0.204 \\
Fiscal incentive & $1.045^{* *}$ & $1.644^{* * *}$ & -0.217 \\
Export in previous year (dummy) & $3.194^{* * *}$ & $3.223^{* * *}$ & $3.551^{* * *}$ \\
Productivity & $0.0727^{* *}$ & 0.048 & $0.222^{*}$ \\
Employment & 0.0531 & -0.00793 & $0.282^{* * *}$ \\
Foreign capital & $0.00329^{* * *}$ & $0.00201^{* * *}$ & $0.0121^{* *}$ \\
Age & $0.0374^{* * *}$ & $0.0346^{* * *}$ & 0.00962 \\
Age squared & $-0.000721^{* * *}$ & $-0.000240^{* * *}$ & $-0.000669^{*}$ \\
Constant & $-3.843^{* * *}$ & $-4.228^{* * *}$ & $-4.693^{* *}$ \\
\hline
\end{tabular}

Note: ${ }^{*} \mathrm{p}<0.1,{ }^{* *} \mathrm{p}<0.05, * * * \mathrm{p}<0.01$. 
resources such as agriculture and mining. We do not find the effect of costs saving as in Abe and Wilson (2011) who reported that increasing a port's capacity by 10 percent will reduce transport costs of up to 3 percent in East Asia.

PLN power source has a positive effect for the Greater Jakarta area. A higher percentage usage of PLN electricity in the industrial estate will improve a firm's decision to export. The existence of alternative power sources that has excellent reliability made PLN improve their quality of services by providing premium power. The quality is guaranteed from shutting down or flicker. Based on the experiences of respondents who use premium PLN power, a flicker might turn off the large and sensitive production machine. Production costs will increase because the large machines need time to be able to work normally after a flash happens.

Outside of the Greater Jakarta area, PLN electricity has a negative effect which means that the greater portion of PLN power in an industrial estate will reduce tendency to export. This result is influenced by the industrial estate that has a high percentage PLN power usage being mostly occupied by firms that do not export. Conversely, the industrial estate that has its power source is mostly occupied by firms that export. This result indicates that PLN has not been able to meet the capacity or quality of the power required by exporting firms in the industrial estate. Industrial estates have to build its power source according to the needs of its tenants.

PAM water has a positive significant effect on a firm's decision to export in the industrial estate in the Greater Jakarta area, which means that firms in the industrial estate that use PAM water are more likely to export than firms in the industrial estate that does not use PAM water. PAM limitations regarding water supply for the industrial estate caused many industrial estates to meet their water needs by utilising river water or groundwater, especially in the area of Bekasi, Karawang and Purwakarta. Independent water treatment by operators of industrial estates may increase production costs due to the higher price of water. On the other hand, PAM water has a significant negative effect on outside the Greater Jakarta area where more exporting firms are located in the industrial estate that has an independent water source. Conversely, in the industrial estate that uses PAM water, fewer firms are exporting. Like PLN power, there is a tendency that in an industrial estate whose many tenants are exporting have built water installations independently.

The number of tenants has a positive significant effect on export decision of firms in the industrial estate in the Greater Jakarta area. More tenants can improve interaction between firms so that the positive effects of agglomeration becomes more prominent as described by Marshall (1890) and Jacob (1969). From the interviews, we obtained information that the industrial estate with many tenants usually have a major firm or industry (anchor). For example, automotive firms get components from supplier firms that are located in the same industrial estate. Likewise, fiscal incentives have a positive influence on a firm's export decision. More firms receiving fiscal facilities (bonded zone) in the industrial estate increases a firm's tendency to export. This shows the positive effect of the export spillover through the existence of the bonded zone in the industrial estate. Both variables, number of tenants in an industrial estate and number of firms in the bonded zone show that economic agglomeration in the industrial estate significantly influences a firm's decision to export. 
Exports in the previous year, the proxy of sunk entry cost, has a significant positive effect on a firm's decisions to export in Greater Jakarta and outside Greater Jakarta areas. Firms that export in the previous year tend to re-export. The tendency to continue exporting is greater in firms that are located outside the Greater Jakarta area. First-time export of firms located outside the Greater Jakarta area needs a greater sunk entry cost than those in the Greater Jakarta area. The results on the role of previous export status support the empirical study of a firm's decision to export such as Farole and Winkler (2011) and Rodriguez et al. (2013).

Productivity has no significant impact on export decision for firms in the Greater Jakarta area. This result shows that firms with low productivity also export. From the interviews, we obtain information that in the Greater Jakarta area, many firms are not only supplying components to a larger company, but they also export. For firms outside the Greater Jakarta area, productivity has a significant positive effect. This is in agreement with Melitz (2003) who stated that only high-productivity firms could export. The number of workers is insignificant to a firm's decision to export in the Greater Jakarta area. It shows that not only the big firms export but also medium-sized firms. Different results were obtained for firms outside the Greater Jakarta area where big firms have more tendency to export than medium-sized firms.

Foreign capital has a significant positive influence in both the Greater Jakarta and outside Greater Jakarta areas. A high portion of foreign capital encourages a firm to export in the industrial estate. These results support Sjöholm and Takii (2008) who found that foreign capital firms are more likely to export than domestically funded firms in Indonesia. The main reason why foreign capital might encourage export is the involvement of global production chain. Multinational companies established factories in several countries that have different comparative advantages to lower production costs. The interviews suggest that the ownership of almost all industrial estates in the greater Jakarta area are joint venture companies, in which most of the foreign ownership came from Japan and South Korea. The presence of this foreign ownership can foster the confidence of investors to invest in Indonesia and locate their firms in the industrial estate which they managed.

A firm's age has a significant positive effect in the Greater Jakarta and outside Greater Jakarta areas. Older firms have a greater probability to export. This result is consistent with Johanson and Vahlne (1977) who showed that export is a gradual development process. However, when we used squared of age, the coefficient is negative. It means that a firm's age is positively increasing the probability to export, but the marginal increase is decreasing.

\section{Conclusion}

Comparison of decision to export for firms inside and outside of the industrial estate using treatment effect method shows that firms in the industrial estate are more likely to export than those located elsewhere. The industrial estate development policy is effective in encouraging the export performance of manufacturing firms in Indonesia.

A firm's decision to export in the industrial estate is influenced by characteristics of the industrial estate. At the national level, PAM water and fiscal incentives increase 
a firm's tendency to export. As for the regional level, industrial estate characteristics give different results across regions. In the Greater Jakarta area, infrastructure such as PLN power and PAM water, local agglomeration and fiscal incentives improve a firm's tendency to export. The government should build better and reliable infrastructure outside the Greater Jakarta area.

In this study, we have learned the effect of industrial estate characteristics on a firm's decision to export, but their impact on the economy remains to be investigated. Further study is needed considering that the industrial estates in Indonesia are mostly dominated by foreign-owned firms. The increase in exports may not provide optimum benefit to the economy of Indonesia if there is no increase in employment, foreign exchange earnings and technology transfer as suggested by Warr (1989).

\section{References}

Abe, K., \& Wilson, J.S. (2011). Investing in port infrastructure to lower trade costs in East Asia. Journal of East Asian Economic Integration, 15(2), 3-32.

Aitken, B., Hanson, G., \& Harrison, A. (1997). Spillovers, foreign investment, and export behavior. Journal of International Economics, 43(1-2), 103-132.

Akinci, G., \& Crittle, J. (2008). Special economic zone: Performance, lessons learned, and implication for zone development (Foreign Investment Advisory Service (FIAS) occasional paper). Washington, DC: World Bank.

Bernard, A.B., \& Jensen, J.B. (1999). Exceptional exporter performance: Cause, effect, or both? Journal of International Economics, 47(1), 1-25.

Bernard, A.B., \& Jensen, J.B. (2004). Why some firms export. The Review of Economics and Statistics, 86(2), 561-569. https://doi.org/10.1162/003465304323031111

Farole, T., \& Winkler, D. (2011). Firm location and the determinants of exporting in developing countries (Policy Research Working Paper 5780). Washington, DC: World Bank.

Farole, T., \& Winkler, D. (2014). Firm location and the determinants of exporting in low- and middle-income countries. Journal of Economic Geography, 14(2), 395-420. https://doi. org/10.1093/jeg/lbs060

Glaeser, E.L. (2010). Agglomeration economics. Chicago, IL: The University of Chicago Press.

Greenaway, D., \& Kneller, R. (2004). Firm heterogeneity, exporting and foreign direct investment. The Economic Journal, 117(517), F134-F161. https://doi.org/10.1111/j.14680297.2007.02018.x

Greenaway, D., \& Kneller, R. (2008). Exporting, productivity and agglomeration. European Economic Review, 52(5), 919-939. https://doi.org/10.1016/j.euroecorev.2007.07.001

Jacobs, J. (1970). The economy of cities. New York: Vintage Books.

Johanson, J., \& Vahlne, J-E. (1977). The internationalization process of the firm - a model of knowledge development and increasing foreign market commitments. Journal of International Business Studies, 8(1): 23-32.

Kementerian Perindustrian. (2012). Direktori kawasan industri Indonesia 2011-2012. Jakarta: Himpunan Kawasan Industri Indonesia.

Koenig, P. (2009). Agglomeration and the export decisions of French firms. Journal of Urban Economics, 66(3), 186-195. https://doi.org/10.1016/j.jue.2009.07.002

Krugman, P. (1991). Increasing returns and economic geography. Journal of Political Economy, 99(3), 483-499. https://doi.org/10.1086/261763

Krugman, P.R., Obstfeld, M., \& Melitz, M.J. (2012). International economics: Theory \& policy (9th ed.). New York, NY: Addison-Wesley. 
Long, C., \& Zhang, X. (2011). Cluster-based industrialization in China: Financing and performance. Journal of International Economics, 84(1), 112-123. https://doi.org/10.1016/j. jinteco.2011.03.002

Malmberg, A. (2009). Agglomeration. In: R. Kitchin \& N. Thrift (Eds.), The international encyclopedia of human geography (volume 1, pp. 48-53). Oxford: Elsevier.

Marshall, A. (1890). Principles of Economics (1st. ed.). London: MacMillan.

Melitz, M.J. (2003). The impact of trade on intra-industry reallocations and aggregate industry productivity. Econometrica, 71(6), 1695-1725.

Narjoko, D.A., \& Atje, R. (2007). Promoting export: Some lessons from Indonesian manufacturing (Asia-Pacific Research and Training Network on Trade, Working Paper Series, No. 32). Bangkok: Asia-Pacific Research and Training Network on Trade (ARTNeT).

Naudé, W., Gries, T., \& Bilkic, N. (2013). Firm-level heterogeneity and the decision to export: A real option approach (IZA DP No. 7346). Bonn, Germany: Institute for the Study of Labor (IZA).

Porter, M.E. (1998). Clusters and the new economics of competition. Harvard Business Review, 76(6), 77-90.

Roberts, M.J., \& Tybout, J.R. (1997). The decision to export in Colombia: An empirical model of entry with sunk costs. The American Economic Review, 87(4), 545-564.

Rodriguez-Pose, A., Tselios, V., Winkler, D., \& Farole, T. (2013). Geography and the determinants of firm exports in Indonesia. World Development, 44(April), 225-240. https://doi.org/10.1016/j. worlddev.2012.12.002

Sabri, M., Nachrowi D.N., Soetjipto, W., \& Panennungi, M.A. (2016). The role of industrial estate characteristics in the export decision of manufacturing firms in Indonesia. In L. Gani, B.Y. Gitaharie, Z. Husodo, \& A. Kuncoro (Eds.), Competition and cooperation in economics and business: Proceedings of the Asia-Pacific Research in Social Sciences and Humanities, Depok, Indonesia, November 7-9, 2016: Topics in economics and business. Florida: CRC Press.

Schminke, A., \& Van Biesebroeck, J. (2013). Using export market performance to evaluate regional preferential policies in China. Review of World Economics 149(2), 343-367. https://doi. org/10.1007/s10290-012-0145-y

Sjöholm, F., \& Takii, S. (2008). Foreign networks and exports: Results from Indonesian panel data. The Developing Economies, 46(4): 428-446. https://doi.org/10.1111/j.1746-1049.2008.00072.x

Wahyuni, S., Anoviar, A.N., \& Santoso, A.J. (2012). The key success factors of Penang as the Silicon Valley of the East. SBS Journal of Applied Business Research (SBS-JABR), 1(September), 34-47.

Warr, P. (1989). Export processing zones: The economics of enclave manufacturing. The World Bank Research Observer 4(1): 65-88.

Winkler, D. (2013). Trade and regional characteristics in Indonesia. In Farole, T. (Ed.), The internal geography of trade: Lagging regions and global markets (pp. 103-125). Washington, DC: World Bank. https://doi.org/10.1596/978-0-8213-9893-7

World Bank. (2009). World development report 2009: Reshaping economic geography. Washington, DC: Author.

Yi, J., \& Wang, C. (2012). The decision to export: Firm heterogeneity, sunk costs, and spatial concentration. International Business Review, 21(5), 766-781. https://doi.org/10.1016/j. ibusrev.2011.09.001

Zhao, H., \& Zou, S. (2002). The impact of industry concentration and firm location on export propensity and intensity: An empirical analysis of Chinese manufacturing firms. Journal of International Marketing, 10(1), 52-71. 
